\title{
CD-ROM and user education
}

\author{
by Dieter Schmidmaier
}

Director-general Deutsche Staatsbibliothek, Berlin

\author{
Translated by Hannelore Rader
}

Director of Libraries

Cleveland State University

\section{Remarks made to the 13th International Essen Symposium, Universitäsbibliothek Essen.}

ditor's note: While traveling in Germany, former $C \mathcal{\gamma} R L$ News editor George Eberhart met Dieter Schmidmaier, director-general of the Deutsche Staatsbibliothek, Berlin. Mr. Eberhart invited him to share his impressions of western libraries with C d R R News readers. What follows is a summary of his remarks to the Universitatsbibiothek Essen, the 13th International Essen Symposium, held in October 1990, translated by former ACRL president Hannelore Rader.

\section{Foreword}

More than 300 years ago, early in the study year 1648 at the University of Helmstedt, the librarian Melchour Schid held a lecture entitled "bibliothecaria peritia" for students. This lecture founded an educational subject known in Germany as "Nutzerschulung" or "Benutzerschulung," or user education.

\section{The need for user education}

The focus of this report is user education for CDROM resources. Many articles concerning the use of CD-ROM in libraries conclude that in order to make the best use of CD-ROM, user education will be necessary. For example, a survey of students at Oakland University's Kresge Library found that: $60 \%$ were satisfied with their CD-ROM search results; $62 \%$ found that their $\mathrm{CD}-\mathrm{ROM}$ search pro- duced useful references; $36 \%$ found CD-ROM difficult to use; $83 \%$ felt that using CD-ROM saved time. ${ }^{1}$

These findings make it clear that there must be a program of user education for CD-ROM. A user education program should have the following goals:

- familiarize users with CD-ROM systems;

- help users utilize CD-ROM in an effective and efficient way;

- help users understand the rationale behind selecting print, online, or CD-ROM versions of information sources for any particular search;

- assist users in coping with an abundance of information;

- increase and intensify users' knowledge of library use;

- prepare users for the work place, where they will often find modem technology, especially in business, the sciences, and other technical disciplines.

\section{Training library staff}

Before implementing CD-ROM, reference librarians will need to assess the needs of the end users of CD-ROM and establish training programs for reference staff. The librarians who conducted the Oakland University survey found that a needs 
assesment is necessary because: librarians need to know effective methods for teaching users how to use CD-ROM; knowing how users search will help librarians decide which CD-ROM systems to obtain for the library; the more the librarian knows about the CD-ROM searching habits the more the librarian will know about users' information needs. ${ }^{2}$

In any training course it will be necessary to teach basic skills to all new CD-ROM users, but staff in particular will need hardware and software skills. For example, they will need to know how to change compact dises, locations of on/off switches on all equipment, how to add paper and clear jammed printers, and basic knowledge of the computer keyboard. They will also need to know how to enter and exit programs, basic search strategies and use of logical operators, field specific searching, how to download, and the procedures for training new users.

\section{Training library users}

The following general comments can be made based on reading numerous publications concerning CD-ROM user education:

- frequent use of CD-ROM systems leads to better use, and some training is better than no training;
- CD-ROM allows for demonstrations of electronic databases without online costs, permits a comparison of different software for searching, and enables demonstration searching in classrooms lacking phone lines and telecommunications capabilities;

- CD-ROM user education encompasses different kinds of user education programs, but must also take into account the experiences of users with other information sources, information technology, and libraries in general;

- users prefer personal, on-demand instruction for CD-ROM systems to written instructions or group lectures;

- the most common training method is the group lecture with demonstration searching, followed by hands-on experience;

- self-instruction programs such as computerassisted instruction, user guides, and manuals supplement group lectures and on-demand instruction.

CD-ROM user education is a new form of bibliographic instruction and is most necessary when CD-ROM is first introduced into a library.

${ }^{1} \mathrm{~K}$. Schultz and K. Salomon, "End users respond to CD-ROM," Library Journal (February 1990): 56.

${ }^{2}$ Schultz, 56 .

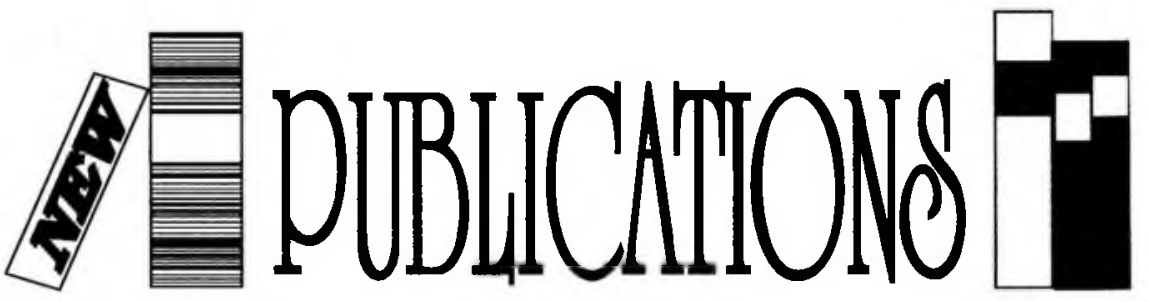

by George M. Eberhart

- African Music: A Bibliographical Guide to the Traditional, Popular, Art, and Liturgical Musics of Sub-Saharan Africa, by John Gray (499 pages, March 1991), covers works from 1732 to the present and offers a comprehensive resource for students and scholars seeking to understand the increasingly popular musics of Africa. The bibliography is divided into six sections: works on cultural policy and the performing arts; ethnornusicology; village or rural music; country or regional studies of African pop music and biographical and critical studies of 275 popular musicians and groups; acculturated or art music traditions; and African church music. Three appendices cover reference works on
African culture, archives and research centers, and a selected discography. Four indexes-ethnic group, subject, artist, and author-complete the work and provide a key to its 5,800 entries. A copy may be ordered for $\$ 55.00$ from Greenwood Press, 88 Post Road West, Box 5007, Westport, CT 06881. ISBN 0-313-27769-9.

- American Capitols: An Encyclopedia of the State, National and Territorial Capital Edifices of the United States, by Eldon Hauck (310 pages, July 1991), describes the genesis, construction, and use of the 56 capitol buildings. The author provides a history of their construction and funding, detailed facts about the architects, notes 